\title{
Dictynna
}

Dictynna

Revue de poétique latine

12 | 2015

Varia

\section{Strings, Triangles, and Go-betweens: Intertextual Approaches to Silius' Carthaginian Debates}

Pramit Chaudhuri, Joseph P. Dexter et Jorge A. Bonilla Lopez

\section{OpenEdition}

1 Journals

Édition électronique

URL : http://journals.openedition.org/dictynna/1156

DOI : 10.4000/dictynna. 1156

ISSN : $1765-3142$

Éditeur

Université de Lille

\section{Référence électronique}

Pramit Chaudhuri, Joseph P. Dexter et Jorge A. Bonilla Lopez, « Strings, Triangles, and Go-betweens: Intertextual Approaches to Silius' Carthaginian Debates », Dictynna [En ligne], 12 | 2015, mis en ligne le 17 mai 2016, consulté le 21 décembre 2020. URL : http://journals.openedition.org/dictynna/1156 ; DOI : https://doi.org/10.4000/dictynna. 1156

\section{(c) (i) (2) $\Theta$}

Les contenus des la revue Dictynna sont mis à disposition selon les termes de la Licence Creative Commons Attribution - Pas d'Utilisation Commerciale - Pas de Modification 4.0 International. 


\title{
Strings, Triangles, and Go-betweens: Intertextual Approaches to Silius' Carthaginian Debates
}

\author{
Pramit Chaudhuri, Joseph P. Dexter and Jorge A. Bonilla Lopez
}

\section{Résumé}

This article examines a case study in Silius Italicus' Punica using two distinct but complementary approaches to Flavian epic intertextuality: a methodological move to expand and further incorporate computational tools within philology, and a literary theoretical move to combine intertextuality and thematic interpretation. The case study focuses on the debates in the Carthaginian senate described in Punica 2 and 11, both of which Silius adapts from similar scenes in Livy while also drawing on Vergil's Aeneid. Part 1 of the essay introduces a new tool for finding a range of inexact verbal parallels based on a bioinformatics technique known as sequence alignment. After comparing the method with two other computational tools, Diogenes and Tesserae, we assess our tool's ability to detect intertexts in the Punica already noted in traditional scholarship. We then analyse a series of computationally identified parallels that have not been commented on previously and find that all three tools can reveal morphologically and syntactically similar phrases of apparent literary interest. Part 2 focuses on a feature of Silius' triangulation of Livy and Vergil, the characterisation of the Carthaginian senator Hanno. Through allusions to Vergil's Drances, Silius turns Hanno from a shrewd judge of Roman character and strength, as he appears in Livy, into a far more ambivalent, Quisling-like figure. Moreover, the effect of blending the two sources is to make more porous the distinctions between nationalities and other categories that structure the reader's response to Hanno and to the Punica as a whole. In concluding, we suggest that the context in which these literary interactions take place - diplomacy and debate - itself figures the kind of negotiation taking place at a textual level between the various works and their worldviews. The conclusion unifies the methodological and theoretical parts of the essay under the rubric of "triangulation", in part by drawing on the application of the term in the philosophy of Donald Davidson.

\section{Entrées d'index}

Index by keyword : Vergil, intertextuality, Silius Italicus, Punica, Aeneid, Livy, Flavian epic, genre, triangulation, Hanno, Drances, Carthage, Rome, fides, debate, diplomacy, metapoetics, sequence alignment, computation, digital humanities

\section{Plan}

Whither Flavian Epic Intertextuality? Explorations in Literary Theory and Methodology

Part 1: The Practice and Perils of Aligning Silius' Carthaginian Debates

Part 2: Problems of Identity, Genre, and Intertextuality in Silius' Hanno

\section{Conclusion}




\title{
Notes des auteurs
}

The introduction and conclusion are the joint work of PC and JPD; Part 1 the work of JBL, with contributions by JPD and PC; and Part 2 primarily by PC. The sequence alignment tool discussed in Part 1 was designed and created by a research group led by JPD and PC, including Nilesh Tripuraneni, Tathagata Dasgupta, Edward Gan, and other contributors. Lea Schroeder contributed part of the data used in Part 1. Our thanks go to Ayelet Haimson Lushkov and the editors of this issue of Dictynna, as well as the two anonymous readers, for insightful criticism and suggestions for improvements. We also thank Neil Bernstein for sharing an unpublished paper on senatorial debate in the Punica; our approach is quite different from, but nevertheless complements, his rhetorical and intertextual analysis. All translations are our own. The project is supported by a CompX Grant from the Neukom Institute for Computational Science at Dartmouth College and a Digital Innovation Fellowship from the American Council of Learned Societies to PC. JPD is supported by a National Science Foundation Graduate Research Fellowship.

\section{Texte intégral}

Pramit Chaudhuri, Joseph P. Dexter and Jorge A. Bonilla Lopez

\section{Strings, Triangles, and Go-betweens: Intertextual Approaches to Silius' Carthaginian Debates}

\author{
Triangles are my favourite shape \\ Three points where two lines meet \\ - Alt-J, "Tessellate"
}

\section{Whither Flavian Epic Intertextuality? Explorations in Literary Theory and Methodology}

So naturalised are the idea and practice of intertextuality to the Latinist that the term has almost become superfluous: Flavian epic intertextuality is nothing more than Flavian epic for what other way would we understand the corpus than intertextually? For many years Latinists have instinctively turned to intertextuality as the dominant hermeneutic paradigm for reasons both historical and methodological. Amply discussed by theorists since Kristeva, its application to Latin literature is well suited to the ancient authors' mode of composition and has yielded especially rich and productive readings. ${ }^{1}$ Thanks to the work of Stephen Hinds and others, building on an already extensive apparatus of older studies of allusion and imitation, intertextuality has become the Latinist's tool of first resort, a powerful means of situating a text within various traditions, discourses, and networks. ${ }^{2}$ Above all, intertextuality 
directs the critic to the multiple points of view created by formal or semantic resemblance of various kinds, whether a single allusive word, a metrical pattern, a topos, or a theme: what is the significance of $\mathrm{X}$ looking similar to, or slightly different from, Y? And what impact does that relationship have on our view of $\mathrm{X}$ or $\mathrm{Y}$ or both? Those questions represent merely the building blocks of more complex interpretive structures, nowhere better illustrated than by the research on Flavian epic itself, which has seen an explosion of work charting its connections to Greek or Augustan predecessors, Neronian or other Flavian poets, and the reception history of the epics in Claudian or post-classical authors, to cite only a few examples. ${ }^{3}$ Given the wealth of existing scholarship, then, this special issue of Dictynna poses two pointed methodological questions: can the study of Flavian epic, in particular, do more than follow existing intertextual models? And, if so, can the resulting contribution affect literary critical practice more broadly, whether in Latin or beyond?

Two serendipitous factors suggest that the answers to the above questions are both yes. First, unlike the Augustan writers, whose prior intertexts are often fragmentary (e.g., Ennius) or almost entirely lost (e.g., many of Nicander's works), the Flavians were heavily influenced by texts that are still extant, and so enable us to engage in more philologically grounded study. Even late antique authors, despite their vantage point overlooking the preceding tradition, suffer because of the significant gaps in our knowledge of the intervening literature. Despite important lacunae, however, study of the Flavians benefits from their reuse of extant canonical and recent material.

3 Second, recent developments in computational approaches to intertextuality, exemplified by the Tesserae Project, have focused especially on epic poetry and Flavian epic, both because of the prior expertise of the researchers involved and because of the inherent suitability of the material for testing methods for large-scale identification of intertexts. ${ }^{4}$ Digital techniques that will prove an essential part of the critic's toolkit are thus being developed using Flavian epic as one key testing ground. For contingent reasons, then, the corpus is well suited to yield insights - whether based on new intertextually-driven commentaries or monographs or digital tools - that are more broadly applicable in literary study.

4 In line with these suggestions, this essay examines a case study in Silius Italicus' Punica using two distinct but complementary approaches to Flavian epic intertextuality: a methodological move to expand and further incorporate computational tools within philology, and a literary theoretical move to combine intertextuality and thematic interpretation. The case study focuses on the debates in the Carthaginian senate described in Punica 2 and 11, both of which Silius adapts from similar scenes in Livy while also drawing on Vergil's Aeneid at key points. The combined application of these moves elucidates - at both a lexical and a thematic level - the composition and dynamics of a "triangular network" between Silius, Livy, and Vergil. Leveraging the substantial survival of Livy and Vergil, the essay interprets the effects of three quite different texts being brought together, which results in striking conjunctions of history and mythology, Roman and non-Roman, one temporal frame and another, one ethical evaluation and another. Part 1 of the essay compares three computational tools for searching for intertextual parallels, first assessing their ability to detect intertexts in the Punica already noted in traditional scholarship. We then analyse a series of computationally identified parallels that have not been commented on previously and find that the tools can reveal morphologically and syntactically similar phrases of apparent literary interest. Part 2 examines a single case study in Silius' triangulation of Livy and Vergil, the characterisation of the Carthaginian senator Hanno. Combining references to Livy's historiographical account with allusions to the Aeneid, Silius turns Hanno from a shrewd judge of Roman character and strength into a far more ambivalent, Quisling-like figure. Moreover, the effect of blending the two sources is to make more porous the distinctions between nationalities and other categories that structure the reader's response. 
Part 2 suggests, finally, that the context of these literary interactions - diplomacy and debate itself figures the kind of negotiation taking place at a textual level between the various works and their worldviews.

Both debate scenes centre on the Carthaginians' confidence in Hannibal and their military prospects against Rome: in the first (Punica 2, Livy 21) Roman envoys demand the surrender of Hannibal, and in the second (Punica 11, Livy 23) Hannibal requests aid to continue the war in Italy. In each scene, the sole Carthaginian to speak against the interests of Hannibal is the anti-Barcid politician Hanno, whose accurate predictions about the course of the war are rejected by the Senate. Throughout our sources Hanno is a fictionalised rather than strictly historical or fictional character, though the difference can be difficult to pin down. A Carthaginian statesman active for much of the $3^{\text {rd }}$ century BC, Hanno is depicted by one Roman or Rome-friendly writer after another, from Polybius to Livy. Whatever fictionalising and elaboration went into the characterisation of Hanno - for who could really know the true inner workings of the historical Carthaginian senate and its personalities? - it's no surprise that he is treated favourably in the Roman tradition. As the historian Appian tells us, after the end of the Second Punic War Hanno would end up leading the pro-Roman faction in the Carthaginian senate (App. Pun. 68). Silius takes a novel approach to emphasising Hanno's political allegiances: when at the end of the first century AD - three hundred years after the Second Punic War - Hanno appears in the Punica, he is presented as a hybrid of his historiographical self in Livy and Vergil's notoriously pro-Trojan Drances. As a mediator of Roman interests and as a locus for generic and ethnographic interplay, Silius' Hanno - even more so than Livy's - provokes a number of questions that bear on interpretation of the epic: what would it mean for the Carthaginians to heed Hanno's advice, in terms of both plot and national identity? What are the effects of his being characterised in an emphatically hybrid way?

A central premise of the essay is that understanding this hybridity requires granular attention to Silius' intertexts and systematic integration of identified intertexts into a broader interpretive framework. Both accumulation and interpretation of the intertexts are coloured by the triangular relationship between Silius, Livy, and Vergil. The Punica is the point at which Livy and Vergil meet, and a complex remixing of Livy and Vergil underlies key aspects of the Carthaginian debates, including especially Silius' characterisation of Hanno. This sort of triangulation of (inter)texts is not new; already in the 19th century, commentators noted that Silius' Hanno resembled both Drances and Livy's Hanno. ${ }^{5}$ Interrogation of such combinatorial allusions, to use the term coined by Philip Hardie more than a quarter-century ago, has been productive across Latin epic. ${ }^{6}$ Standard discussions of combinatorial allusion, however, have often privileged one source over another in the identification of "primary" and "secondary" intertexts, and have not dealt much with cases more complicated than triangulation (such as one:many and many:many intertextual networks). Our approach to triangulation extends conventional thinking about combinatorial allusion in two important ways. It first leverages multiple computational approaches, each with distinct strengths and weaknesses, to build a rich portrait of text reuse not fixated solely on "blockbuster" parallels. Using this data, it then maps (microscopically and macroscopically) the "shared world" that arises from the simple process of going from two texts to three. ${ }^{7}$ In our case study, this mapping reveals Silius' depiction of diplomatic debate as a metapoetical model of his own negotiation of Livian and Vergilian influence.

Triangular thinking need not be restricted to cases in which two (source) texts converge at a third; higher-dimensional analogues fit readily into the framework (and are not uncommon in ancient literature) ${ }^{8}$ An attendant goal of the article is therefore to model, through rigorous consideration of an exemplary triangular case, how a critic might in the future "n-angulate" larger intertextual networks. ${ }^{9}$ Recognising the scalability of the framework in turn highlights 
the centrality of computation to it. Even with $n=3$, it is easy to appreciate the challenge of filling in the intertextual profile using only manual review and critical intuition. For bigger networks the problem gets much worse. As $n$ increases linearly the number of pairwise comparisons that must be made between texts increases much faster than linearly. This sort of "combinatorial explosion" is familiar in computer science, where many otherwise elegant algorithms are unusable in practice because they quickly require an absurd number of computations for larger inputs. The way around an inefficient algorithm is to develop a good heuristic, sacrificing exactness for speed. In the study of intertextuality, digital tools might be seen as a sort of heuristic for the classicist, allowing one to get a ready - but inevitably incomplete and noisy - handle on intertextuality in texts of any reasonable size.

With an eye toward the burgeoning role of computation in classics, this essay is interspersed with reflections on both the theory and practice of digital intertextuality. Three computational tools were used to generate data presented here: Diogenes, a word search tool that has long been an integral component of the philologist's toolkit; Tesserae, an innovative approach to find repeated two-word phrases between pairs of texts; and a new method developed by our team for finding a range of inexact verbal parallels based on a bioinformatics technique known as sequence alignment. Of particular interest, Part 1 of the essay offers a practical introduction to the use, strengths, and limitations of sequence alignment.

\section{Part 1: The Practice and Perils of Aligning Silius' Carthaginian Debates}

Part 1 reports a practical evaluation of the use of computational search to detect intertextual parallels of literary significance. We provide a concise introduction to our recently developed sequence alignment tool and evaluate its ability to identify parallels generated using two existing digital search tools (Diogenes and Tesserae) or reported in a traditional commentary (François Spaltenstein's Commentaire des Punica de Silius Italicus). ${ }^{10}$ Searches involving key phrases from the debate scenes in Punica 2 and 11 demonstrate that sequence alignment is well suited to detect language linguistically or morphologically similar, though not necessarily identical, to source material. We then examine in detail intertextual parallels found using sequence alignment that link the embassy scene in Punica 2 with the Aeneid and with Hannibal's crossing of the Alps in Livy 21.

10 Sequence alignment is a method to compare two "strings" of arbitrary characters. This comparison is made on a character-by-character basis. "Alignment" means to position the strings side-by-side so that they match (i.e., have an identical character) at as many positions as possible. For an aligned pair of strings, a score known as the edit distance quantifies similarity - points are added to a tally for identical characters and subtracted for mismatches or gaps. ${ }^{11}$ As such, a more precise definition of the edit distance is the minimum number of single-character changes (additions, deletions, or substitutions) required to convert string $\mathrm{A}$ into string B. For instance, the edit distance of $\mathrm{A}=$ "kitten" and $\mathrm{B}=$ "sitting" is 3 because three changes (substitution of "s" for k", substitution of "i" for "e", and insertion of the final "g") are required to turn A into B. Sequence alignment is foundational to genomics and bioinformatics, where tools like BLAST (Basic Local Alignment Search Tool) are used to search for homologous (similar) gene or protein sequences across large databases. ${ }^{12}$ To mention just one typical application, a biologist might want to track the presence or absence of a gene across many different species, so as to gain a better understanding of their evolutionary history. A crucial point is that homology between genes is never exact. Therefore, searching for identically matching sequences, although computationally easy, is not useful. The solution now universally adopted in bioinformatics is to do sequence alignment. 
Inexact matching, of course, is also central to the study of intertextuality. If the computational identification of intertexts is to become as routine and useful as finding homologous genes, methods that can flexibly account for the "fuzzy logic" of Latin intertextuality, to borrow Stephen Hinds' prescient metaphor, are likely to play an important role. ${ }^{13}$ With this goal in mind, we have developed a sequence alignment search tool, a sort of "BLAST for literature" that allows users to identify phrases (of arbitrary length) most similar on a character-bycharacter basis. ${ }^{14}$ The tool requires the user to enter a phrase and set as a parameter a "cutoff" score (the maximum edit distance score tolerated, with lower scores indicating better homology). The choice of cutoff has important consequences - an overly permissive cutoff can lead to a frustratingly low signal to noise ratio, while an overly restrictive one can screen out parallels of potential interest. A rough standard is to set the cutoff at 5 for bigram searches and between 10 and 15 for trigrams. ${ }^{15} \mathrm{We}$ emphasise, however, that the cutoff is not a direct predictor of the significance of a potential parallel - banal intertexts inevitably arise even with restrictive searches, and lexically dissimilar parallels can sometimes be of great literary interest.

12 We envision sequence alignment as a useful complement to Diogenes and Tesserae, which can identify repeated (pairs of) words and therefore trade some of the flexibility of sequence alignment for improved signal to noise ratio. Diogenes is a browsing and search tool that can be used to find common words (either exact repeats or differing by one or more "wildcard" characters) in texts of interest. ${ }^{16}$ The core Tesserae tool generates lists of repeated two-word phrases (ranked by inter-word distance and commonness of the words) for arbitrary pairs of Latin (or Greek) texts. ${ }^{17}$ In 2012 the Tesserae Project reported a systematic tracing of the reuse of the Aeneid in the Pharsalia, which provided an impressively granular picture of Lucan's composition. ${ }^{18}$ Their approach can be repeated with any other pair of texts and has already been pursued for Flavian epic. ${ }^{19}$

13 Our sequence alignment tool operates on a particular phrase determined by the user, rather than comparing texts globally (as Tesserae does). As such, it requires judicious selection of input terms. The search corpus consisted of Punica 2 and 11, Livy 21 and 23, and the entirety of the Aeneid. In our searches, we usually entered phrases that were a point of focus or emphasis in the passages, such as noun-adjective pairs, head noun-dependent noun pairs (usually including a subjective or objective genitive), and verb-direct object pairs. To sort through long lists of potential parallels generated, we prioritised phrases syntactically and lexically similar to the entered search terms. As a general rule of thumb, we utilised a cutoff of 5 to conduct searches for bigrams (that is, two-word phrases) and a cutoff of 10 for trigrams. Cutoff values were subsequently adjusted based on the amount of data the tool produced. If a cutoff value produced few results for a given query, for example, the value would be raised incrementally. The Diogenes and Tesserae tools were not used systematically, but were rather deployed for ad hoc comparisons with the results generated through sequence alignment or with parallels reported by Spaltenstein.

14 We begin our methodological report with a failure. In several cases, all three tools were unable to detect a parallel listed by Spaltenstein. The tools commonly failed on lemmata that note scenes evoking a similar mood or utilising the same motif without much shared language. Consider, for instance, his comparison of Punica 2.312-14 (scilicet, immensae, uisis iuuenalibus armis, / subsident Alpes, "of course, the immense Alps will subside at the sight of the youth's arms") and Livy 21.10 .8 (nec puer hic dux erat, "nor was this boy general"). Though Hanno emphasises Hannibal's youth in both passages, they share no verbal parallels and, consequently, the similarity is missed computationally. Detection would likely require a tool that picks up on the semantic relationship between iuuenalibus and puer. ${ }^{20}$

The tools were often successful, however, in detecting verbal intertexts. The sequence alignment tool produced a parallel, also identified by Spaltenstein, between Silius' Hanno and 
Vergil's Drances, both of whom claim to be threatened with violence: neque enim cohibere minantum / irae se ualuere, Sil. 2.279-80; dicam equidem, licet arma mihi mortemque minetur, Aen. 11.348. A search for minantum irae with a cutoff at 9 yielded minetur. / lumina (Aen. 11.348-9). While the tool detected the parallel between Silius' minantum and Vergil's minetur, the result also included the word lumina, which is not part of the intertext. Nevertheless, this example illustrates the useful capaciousness of the tool. It is mere coincidence that lumina happens to contain characters also found in minantum irae, thereby causing the Vergilian phrase to appear among the results. But sequence alignment allows us to catch such chance intertexts, which other methods would either exclude on grounds of insufficient similarity or include only when using very broad parameters. If one sought to identify the same intertext through Diogenes, for instance, the lack of any substantial similarity (the only shared element is min-) would be a major obstacle. Tesserae would face a different, but equally critical, problem - the apparent absence of any second shared word. ${ }^{21}$ The capaciousness of sequence alignment is double-edged, however, since many phrases composed of the same or similar letters are not related in any meaningful way. It is therefore incumbent on the user to exercise some judgement in determining suitable cutoffs and sorting through more and less meaningful results.

The intertext between Aen. 11.348 and Sil. 2.281 contains three common words (licet, arma, and mortem) and is therefore so overt that it can be detected with relative ease by all three tools. Sequence alignment is specifically useful for revealing a parallel (unremarked upon by Spaltenstein) between mortemque minetur in the Vergilian line and and toruumque minatur at Sil. 2.431, where it describes the ferocity of Hamilcar's imago as depicted on the shield of Hannibal. It is something of an ideal parallel for sequence alignment - although there is just one shared word (that is morphologically variant) between the lines, the edit distance of mortemque minetur and toruumque minatur is only 4. Drances' focus in the midst of a speech on the physical threat of arma is perhaps an appropriate recollection for the Silian ecphrasis.

The strength of sequence alignment is clear in identifying parallels that share linguistic units such as morphological endings, as with -tur in the above example. ${ }^{22}$ A search for coquebat I ... iras (Sil. 2.327-8) at a cutoff of 6, for instance, yielded aggerat iras (Aen. 11.342), a parallel noted by Spaltenstein. In this case, the tool located the Vergilian phrase because of the combination of the shared word iras and the -at endings of both verbs. Tesserae did not pick up the similarity between aggerat iras and coquebat /... iras because of the absence of any other shared word besides iras. In contrast, Tesserae excels at identifying lexically similar parallels in which the individual words are separated. For instance, Tesserae detected the parallel between Sil. 2.287/291 (monui et, dum uita monebo ... / praedicit miseris haud uanus flamina nautis) and Livy 21.10 .3 (monuisse, praedixisse se, ne Hamilcaris progeniem ad exercitum mitterent), passages that share forms of moneo and praedico, as Hanno claims that he had "warned" and "foretold" the Carthaginians about the danger Hannibal would pose.

18 Sequence alignment was also useful for identifying parallels not noted by Spaltenstein. Our search results suggest the Aeneid often operates, to borrow Conte's famous formulation, as a "code model" for Silius, in which an allusion to a model phrase or passage is deployed "for its generic qualities without evoking a meaningful analogy". ${ }^{23}$ Our searches using sequence alignment yielded twelve parallels of apparent significance between the Punica and Aeneid (listed in Table 1), of which the majority seem to be of the code model variety. 
Table 1. Parallels between the Punica and Aeneid detected by sequence alignment.

\begin{tabular}{|l|l|l|}
\hline Punica Input Phrase & Potential Intertext from Aeneid & $\begin{array}{l}\text { Edit } \\
\text { distance }^{24}\end{array}$ \\
\hline conuersi foedere rupto (2.297) & $\begin{array}{l}\text { nec foedera rumpet (12.202) } \\
\text { altera foedera rumpi (12.582) }\end{array}$ & 11 \\
\hline impatiens asperque coquebat (2.327) & impatiens arrecto pectore (11.639) & 15 \\
\hline tritas / desperare uias (2.356-7) & ignotas temptare uias (8.113) & 8 \\
\hline primi incendia belli (2.358) & $\begin{array}{l}\text { tanti incendia belli (1.566)* } \\
\text { coepti fiducia belli (2.162) }\end{array}$ & 4 \\
\hline ponat formidinis aestus (2.360) & coit formidine sanguis (3.30) & 11 \\
\hline rapido circumdat gurgite (11.507) & nigro circumdata turbine (11.596) & 10 \\
\hline inuidia atque ira stimulantibus (11.543-4) & dictis atque aggerat iras (11.342) & 9 \\
\hline $\begin{array}{l}\text { pacem orandum ... arma reponendum }{ }^{25} \\
\text { (11.559-60) }\end{array}$ & pacem Troiano ab rege petendum* (11.230) & 19 \\
\hline aeratas iussi texamus (11.586) & denas Italo texamus* (11.326) & 16 \\
\hline belli posceret usus (11.607) & bello: pacem te poscimus omnes* (11.362) & 10 \\
\hline
\end{tabular}

*These parallels are noted by Spaltenstein.

Italics denote those words germane to the queried phrase but not part of the computational alignment.

19 Several of the intertexts in Table 1 above are superficial evocations of Vergil's language and syntax in the Aeneid. For instance, in Punica 11 rapido circumdat gurgite refers to the river Aufidus flooding the Apulian plains, while in Aeneid 11 nigro circumdata turbine refers to the enveloping of Opis' body in a dark whirlwind as she retrieves Camilla's corpse. Both phrases have an A-B-A (adjective-verb-noun) structure and share nearly identical diction. Moreover, both phrases are located in the exact centre of five word lines and occupy the middle four feet of the line. In each case, however, the phrase is applied somewhat differently and seems primarily intended to provide evocative description. It is reasonable to infer, then, that Silius has drawn on Vergil's language for stock purposes without any further implications, though the incorporation of a phrase from Aeneid 11 is in keeping with Silius' systematic use of the Latin debate from the same book. Furthermore, of the twelve parallels listed in Table 1, nine refer to the second half of the Aeneid. This concentration reflects the generally greater correspondence in subject matter between the Second Punic War and the Italian War (as opposed to Aeneas' Odyssean voyage). In this context, even relatively generic intertexts of the code model sort can, in sufficient quantity or density, contribute to a larger sense of the Punica as a sequel to the Aeneid and its Italian War in particular, a point developed further in Part 2.

20 There are other parallels that at first appear to be instances of code models, or even of mere coincidental reuse, but upon closer inspection have a claim to greater significance. The similarity between the phrases primi incendia belli in Punica 2 and tanti incendia belli in Aeneid 2, for example, does not at first glance appear to be of any interpretive consequence. Gestar uses the former of the "conflagration" of the First Punic War, whereas Dido uses the 
latter in relating how the "blaze" of the Trojan War - alluding to the sack of the city - has gained global notoriety. Despite (or perhaps even owing to) the invocation of a war in both passages, Silius seems to have appropriated the structure and (most of) the language of this phrase for generic reasons - perhaps because, in Spaltenstein's words, "[1]e feu symbolise la guerre." ${ }^{26}$ Moreover, each three-word phrase occupies half of its respective line and possesses an A-B-A structure, and so may function in a relatively formulaic way. ${ }^{27}$ Prompted by these similarities, one may press the intertext into service as an allusion to the Trojan War and especially to the place of the Trojan War within the Aeneid. On this view, the First Punic War assumes the fame of Vergil's Trojan War, becoming a global phenomenon nevertheless destined to be exceeded by the current war (and subject of Silius' epic). Furthermore, the image of fire ties Vergil's sack of Troy to Silius' fascination with the burning of cities from Saguntum (programmatic) to Rome (hypothetical) to Carthage (proleptic), and even to the near contemporary Rome of 69 AD (allusive). Like the code model intertexts with Vergil's Italian War, this intertext also creates continuity between the wars of the Aeneid and the Punic Wars, and between their shared mythological origins in the anger of Juno against the Trojans and their Roman descendants. Silius' incendia belli thus not only builds on a natural association between fire and war, as Spaltenstein suggests; through its allusive reach, the phrase also evokes the spread of those flames from one war to another, one city to another, one cause to another, and one epic to another.

21 The sequence alignment tool also detected parallels between the Punica and Livy's Third Decade. At the end of his speech in Punica 2, Hanno claims he will have saved Carthage from much bloodshed if she should ultimately refrain from war (si bello absistis, 2.325). A similar conditional construction appears at Livy 21.6.6, where the envoys P. Valerius Flaccus and Q. Baebius Tamphilus are to go to Carthage to demand Hannibal's surrender if he does not cease hostilities (si non absisteretur bello). ${ }^{28}$ The passages share other verbal parallels, mostly concerning the exacting of punishment as a response for the supposed violation of the Ebro Treaty. Hanno, for instance, asserts that the gods have turned against the treacherous Hannibal as a result of the broken treaty (conuersi foedere rupto / in caput infidum superi, Sil. 2.297-8) and expresses his hope that Hannibal pay the penalty for his actions without involving Carthage in his lot (sic propria luat hoc poena, 2.301). Similar phrasing is found in Livy, when he relates that the two envoys are to demand Hannibal's individual surrender as punishment for the broken treaty (ducem ipsum in poenam foederis rupti deposcendum, 21.6.6). As a whole, these resemblances offer a revealing view of Silius' compositional practice, which is to draw on Livy's language while deploying it with certain changes, such as by putting it in the mouth of different speakers. The effect of attributing the Roman ambassadors' language to Hanno, in particular, confers upon him a distinctly Roman quality, a point developed further in Part 2.

Another query, which also appears in Table 1 as intertextual with the Aeneid, was the phrase tritas / desperare uias, which yielded trita antea, quamuis (Livy 21.36.5) with the cutoff set at 13. The speaker, Hanno's opponent Gestar, uses the phrase tritas uias in anticipation of the Carthaginians' crossing of the Alps and, accordingly, their repetition of one of Hercules' glorious feats: pudet Hercule tritas / desperare uias laudemque timere secundam; "it is shameful to despair of paths trodden by Hercules and to fear repeating his glory," Sil. 2.3567). The corresponding phrase appears in Livy precisely at the moment when Hannibal is crossing the Alps with great difficulty and the general sees that there is no recourse but to traverse pathless and untrodden tracts of snow (haud dubia res uisa quin per inuia circa nec trita antea, quamuis longo ambitu, circumduceret agmen, Livy 21.36.4). While sequence alignment here profits from the chance similarity between Silius' uias and Livy's quamuis, the example well illustrates the strength of the technique in accommodating passages that might otherwise elude detection. trita- is the only element strictly common to both passages, 
to which a "manual" reading of the text can add -uia. Silius will go on to describe Hannibal's crossing in great detail in Book 3, a passage that bears numerous similarities to Livy's account. Gestar thus gives the reader a foretaste of the substantial intertextual engagement to come but, while his intent is to glorify Hannibal's imminent feat, he in fact makes the crossing sound less challenging than it is. In the process, he accidentally diminishes the scale of Hannibal's achievement - not a retreading of the same path already forged by Hercules, but rather, as the Livian account relates, a new and hazardous route. Indeed, in Book 3 Silius will explicitly describe Hannibal instructing his men to depart from the tracks of Hercules and proceed on a new path (Sil. 3.512-17). ${ }^{29}$

23 We hope the examples discussed in this section hint at the potential usefulness of sequence alignment as a (scalable) starting point for in-depth analysis of individual and collective intertexts. In particular, sequence alignment enables the discovery of parallels that rely on morphological - in addition to lexical - similarities between words and phrases. As with all such tools, the technique is best employed in conjunction with multiple search methodologies and in consideration of the manifold significance of literary intertextuality. It is to this latter aspect that we now turn.

\title{
Part 2: Problems of Identity, Genre, and Intertextuality in Silius' Hanno
}

The triangulation of Silius' Hanno with his Livian model and Vergil's Drances is not in itself new. Already in the $19^{\text {th }}$ century Drances was compared to Livy's Hanno, and Silius' Hanno to Drances. ${ }^{30}$ More recently, the copious list of verbal parallels and thematic similarities in Spaltenstein's commentary includes several references to both of Silius' models. ${ }^{31}$ No attempt, however, has been made to interpret the triangulation. ${ }^{32}$ Here we suggest that the resemblance to the dubious figure of Drances undermines Hanno's essentially panegyrical view of the Romans in two ways: first, by reducing his moral authority, and second, by casting Silius' Carthaginian debates as a reflection of the Latin debate in the Aeneid, a scene of intra-societal tension evocative of Rome's recent and past civil strife. In this way, the Vergilian strand running through Silius' representation of Hanno complicates the more positive characterisation inherited from Livy. As with all intertextual characterisation, however, the interpretive consequences are interesting precisely for their uncertainty: Silius' Hanno may function as a re-reading of Livy's Hanno, Vergil's Drances, both, or neither, depending on the reader's view of all three works. ${ }^{33}$ What is clear, however, is that Silius' allusive practice signals his debt to Livy and Vergil, and that in so doing he invites the reader to reflect on the significance of the triangulation.

Silius introduces the debate in such a way as to suggest a clear evaluation of right and wrong (Sil. 2.273-6):

\author{
mouet hinc foedusque fidesque \\ et testes superi iurataque pacta parentum, \\ hinc popularis amor coeptantis magna iuuentae, \\ et sperare iuuat belli meliora. \\ On this side they were moved by the treaty and good faith, \\ the gods who witnessed it, and the pact sworn by their fathers; \\ on the other by the popularity of the ambitious young man, \\ and they enjoyed the hope of victory in war.
}

Silius leaves no room for confusing the moral quality of the two sides: trustworthiness, gods, and sticking to the promises made by one's father, on the one hand; the popularity and ambition of a precocious youth (i.e., Hannibal) and a false hope of victory, on the other. The 
strong connection between the formal obligations of a treaty (foedus) and the abstract characteristic of good faith (fides) is made clear by the collocation foedusque fidesque - a play on sound, an etymological connection, and a hendiadys. ${ }^{34}$ Despite this apparently Manichean distinction between the two parties in Carthage, however, we shall subsequently see that the word fides operates more subtly than the glib jingle of foedusque fidesque might suggest. ${ }^{35}$

27 Immediately following this sketch of the two positions, Silius has Hanno speak as the representative of those who would abide by the Ebro treaty and hand over Hannibal to the Romans. Before Hanno begins, however, Silius describes him in terms that recall not Livy's Hanno, who is characterised largely positively (e.g., 21.4.10), but rather Vergil's figure of envy and sedition, the Latin senator Drances (Sil. 2.276-7). Since this is merely the first of several allusions assimilating Hanno and Drances in both debates, for the sake of economy the most important intertexts are presented in Table 2.

Table 2. Parallels between the Punica and Aeneid involving Hanno and Drances.

\begin{tabular}{|c|c|}
\hline Punica & Aeneid \\
\hline $\begin{array}{l}\text { sed, olim } \\
\text { ductorem infestans odiis gentilibus, Hannon } \\
(2.276-7) \\
\text { But Hanno, long hostile to the leader because of familial } \\
\text { hatred }\end{array}$ & $\begin{array}{l}\text { tum senior semperque odiis et crimine Drances } \\
\text { infensus iueni Turno } \\
(11.122-3) \\
\text { Then Drances, an elder, ever hostile in his hatred and } \\
\text { accusations against the young Turnus }\end{array}$ \\
\hline $\begin{array}{l}\text { haud tamen abstiterim, mortem licet arma propinquent. } \\
\text { (2.281) } \\
\text { Yet I will not withdraw, though a violent death threaten } \\
\text { me. }\end{array}$ & $\begin{array}{l}\text { dicam equidem, licet arma mihi mortemque minetur } \\
\text { (11.348) } \\
\text { Indeed, I shall speak, though he threaten me with a } \\
\text { violent death. }\end{array}$ \\
\hline $\begin{array}{l}\text { frigida corda } \\
(2.339) \\
\text { frozen heart }\end{array}$ & $\begin{array}{l}\text { frigida dextera } \\
(11.338-9) \\
\text { frozen hand }\end{array}$ \\
\hline $\begin{array}{l}\text { quem gliscens gloria prauum } \\
\text { ductoris studio iam dudum agitabat acerbo } \\
\text { (11.543-4) } \\
\text { a crooked man whom the swelling glory of the leader } \\
\text { long since provoked to bitter partisanship }\end{array}$ & $\begin{array}{l}\text { tum Drances idem infensus, quem gloria Turni } \\
\text { obliqua inuidia stimulisque agitabat amaris } \\
\text { (11.336-7) } \\
\text { Then Drances rose, hostile as before, whom Turnus's } \\
\text { glory provoked with the bitter sting of glancing envy. }\end{array}$ \\
\hline $\begin{array}{l}\text { cui, simul inuidia atque ira stimulantibus, Hannon } \\
\text { (11.554) } \\
\text { to whom Hanno, at once stung by envy and anger }\end{array}$ & $\begin{array}{l}\text { surgit et his onerat dictis atque aggerat iras. (11.342) } \\
\text { He rose and loaded his words with heaps of wrath. }\end{array}$ \\
\hline
\end{tabular}

28 Despite Silius' clearly systematic comparison of the two figures, it's important to recognise that the reader only realises the full extent of this relationship when seeing the same associations recur in the speech responding to Hanno (Sil. 2.339), and twice in Book 11. In other words, the hint of dubiousness that precedes and colours Hanno's first speech grows in emphasis and significance the more we encounter him. Moreover, of the five principal allusions, most of which constitute personal criticisms of Hanno, three are delivered in the voice of the poet rather than an opponent, just as the narrator of the Aeneid had himself explicitly coloured our perception of Drances. And since the allusions are mutually reinforced by the poet and Hanno's own speech, the characterisation is much harder to view 
as the focalisation of an unsympathetic Carthaginian audience. Readers of the Aeneid implicitly Romans - are thus cued to be suspicious of the only Carthaginian character who touts the poem's own pro-Roman rhetoric and gives the Carthaginians largely sound advice, a suspicion strengthened by Silius' repeated allusions to Drances. Finally, and most strikingly, the effect of the allusions is to assimilate Roman readers of the Aeneid and the internal Carthaginian audience, both of whom - for very different reasons, but arguably in similar ways - feel suspicious of Hanno. Already, then, we see how intertextuality works to create cognitive effects that transcend the simple binary oppositions implied by such formulations as foedusque fidesque and Punica fides.

29 Without entering too deeply into the scholarly discussions of Vergil's Drances, for which there's insufficient space here, it's nevertheless important to register one crucial disagreement with the current orthodoxy. Pulled in by the magnetic force of what we know will be the result of the Italian war, one can easily confuse what occurs in practice with what ought to happen - fact and value - especially from a Roman perspective, since the outcome will be the victory of Aeneas and the eventual foundation of Rome. It's that instinct that leads critics to see the negatively characterised Drances as little more than the wrong man bearing the right message. In Philip Hardie's reading, for instance, Drances makes us uneasy about rhetoric and perhaps even speech in general, but his policy of appeasement is nevertheless "the one that the Latins should be following." 36 This is not, however, the only possible, or even plausible, view. For if Drances' appeasement is read not as a tolerable compromise but rather as utter self-abnegation on behalf of the Latins, and if his envy and dissension indeed foreshadow the political ills that will befall Rome, as many critics including Hardie have suggested, the supposed merits of his policy are in fact considerably more ambiguous than Hardie allows. ${ }^{37}$ In other words, the decision to follow a political policy may not be separable from - indeed, may entail - following the proponent of the policy, and when that proponent resembles Drances the consequences of granting such a figure authority are potentially dire. Whether readers ultimately remain open to this more pessimistic interpretation or favour Hardie's pragmatic view, however, one thing is clear: Silius has used Vergil's Drances to contaminate Livy's sympathetic portrayal of an optimate Hanno starkly distinguished from his reckless brethren among the army, plebs, and senate (cf. Livy 21.3.4-4.1). In his exchange with Mago in the second debate, Livy's Hanno forces Mago to acknowledge the resilience of the Romans (Livy 23.12.15-13.4). Silius inflates this judicious appraisal into a panegyric of grotesque proportions, which the poet places in the first debate (Sil. 2.318-24):

pubescit castris miles, galeaque teruntur
nondum signatae flaua lanugine malae,
nec requies aeui nota, exanguesque merendo
stant prima inter signa senes letumque lacessunt.
ipse ego Romanas perfosso corpore turmas
tela intorquentis correpta e uulnere uidi,
uidi animos mortesque uirum decorisque furorem.

Their soldiers grow up in military camp, and their cheeks rub against the helmet before they're marked by the golden stubble. Nor is rest known to them with age; even old men, blooded by long service, stand in the front rank and provoke death. I myself have seen Roman squadrons, when run through the body, seize the weapon from their wound and hurl it at the foe; I have seen their courage, their manner of dying, and their passion for glory. 
often associated with Silver Latin literature, and which might be taken to normalise Hanno's rhetoric. Once again, Silius draws on Drances, this time not from the Latin debate but from the embassy to Aeneas, in which Drances praises the Trojan hero to the heavens (Aen. 11.124-6). The intertext here is behavioural rather than verbal, but it nevertheless elaborates the connection between Drances and Hanno, and further distorts the Livian image.

Moreover, the first two lines of the Silian passage contain an ambiguity that punctures Hanno's puffed up oratory: the very terms in which Hanno praises the Romans - as reared for warfare - apply most obviously to Hannibal himself, who was almost proverbially said to have been raised in camp. Indeed, earlier in the very same speech Hanno had claimed to have warned against the dangers of Hannibal being reared in camp (ne castris innutriretur, Sil. 2.286). This explains why Silius shifts Hanno's praise of the Romans from the second debate to the first - to highlight the apparent inconsistency in his speech. Those who might try to defend Hanno as contrasting Hannibal and the Romans face the obvious objection that Hanno himself fails to draw attention to this contrast: he leaves implicit what requires - certainly to his internal audience - explicit distinction. Since Hanno is perfectly capable of making such clear distinctions regarding Hannibal elsewhere, the omission suggests that in fact he doesn't notice the implicit praise of Hannibal (or criticism of the Romans) entailed by this intratextuality, and thus he likewise doesn't notice the undermining of his own argument.

But there is a still more damaging problem for Hanno. The passage's second line contains a further intertext, a generic reference to the appearance of beautiful young men. The diction recalls, in particular, Vergil's apostrophe to the Italian warrior Cydon pursuing his youthful beloved Clytius (Aen. 10.324-5): tu quoque, flauentem prima lanugine malas / dum sequeris Clytium infelix, noua gaudia, Cydon ("You too, unhappy Cydon, while you followed Clytius, your new delight, his cheeks blond with the first down"). ${ }^{38}$ What distinguishes the significance of Hanno's language from mere poetic idiom, however, is the context provided by his own speech, but taken from Livy rather than Silius. In Livy, Hanno had specified the reason for arguing against Hannibal's rearing in camp, offering grounds we don't find in the Punica: by placing vulnerable youths at the mercy of the commanders, the practice perpetuated a series of sexual abuses - of Hasdrubal by Hamilcar, and now of Hannibal by Hasdrubal - that licensed the lusts, and ultimately the despotic tendencies, of these generals (Livy 21.3.5-7). And yet, despite these Livian morals, Silius' Hanno speaks in admiration even loving admiration - of boys raised in military camp, like Hannibal himself, boys not even at the point of showing the first, eroticised traces of adolescence. In that light, it may be reasonable to wonder whether, according to Hanno, the Romans have a passion for glory or, with decoris understood somewhat differently, a passion for beauty. Through the intertwining of Vergil and Livy, then, Silius creates an ironic distance between the audience of the Punica and Hanno, allowing the character to seem far more dubious to that audience than was warranted by the Livian model, at least. Moreover, Silius achieves this effect not only through the global appropriation of Vergil's Drances but also through local allusion to elements of the Aeneid - such as Cydon's pederastic love - which further complicate the character of Hanno.

Hanno's hypocrisy aside, there is perhaps a more salient point about his praise of Roman courage. Its tone is so obviously misplaced for the internal audience of Carthaginians, it's almost as if Hanno imagines himself speaking before a completely different audience, one altogether more sympathetic to his values - in other words, a Roman audience. It's little surprise, then, that Hanno's opponent in Punica 2, likely an invention of Silius' named Gestar, accuses Hanno of being an enemy of the Carthaginians (Sil. 2.330-2; cf. Livy 23.12.4-6): 
"concilione" inquit "Libyae Tyrioque senatu,
pro superi, Ausonius miles sedet, armaque tantum
haud dum sumpta uiro? nam cetera non latet hostis."
"In the council of Libya", he says, "and in the Tyrian senate,
by the gods - does a Roman soldier sit here? All that's missing
is for the man to take up arms - as for the rest, the enemy is in plain view."

The speaker, whom Silius describes in negative terms as intolerant, harsh, and angry (Sil. 2.327-8) - hardly a ringing endorsement - responds to Hanno's praise of the Romans by pointing to the Carthaginians' own strengths and achievements. In playing the nationalist to Hanno's appeaser, Gestar continues the larger intertextuality with Aeneid 11. For in opposing the Drances-like Hanno, and reviling his cowardice (Sil. 2.339; cf. Table 2), he takes on the role and even the diction of Turnus in the Latin debate. ${ }^{39}$ Gestar is fiercely proud of Carthaginian independence, a concept framed as a hardworking defence of freedom (pro libertate labores, Sil. 2.359) and a willingness to die rather than see his country enslaved (Sil. 2.366-7): occumbam potius nec te, patria inclita, dedam / aeternum famulam liberque Acheronta uidebo. The discourse of libertas - the defining quality of the Roman republic leaves the curious impression of Gestar's Romanness, even as Hanno had sounded almost parodically Roman in his praise. The phrase pro libertate, in particular, alludes to Vergilian descriptions of Roman republican heroism, including the paradigmatic figure of Brutus. ${ }^{40}$ Thus, both Silian speakers in the first debate - for all that they are opponents - take on a similarly Roman hue from even the most superficial reading of their speeches. This rhetorical colouring is added to dense layers of Vergilian intertextuality, which assimilate Hanno to Drances and Gestar to Turnus, both proto-Roman Latins. As so often in Latin literature, then, a type of ethnography (of the Carthaginians) has become a mirror of the Roman self - a claim which, for all that it might also apply to, say, Livy's history, is massively overdetermined by Silius' compositional and intertextual choices.

Besides these moments of political or historical significance in the Aeneid, which can be seen as commensurate in kind with events in Livy, Silius deploys other types of Vergilian allusion that are more distinctively epic and mythological in nature. When, for instance, Gestar boldly declares that he would rather die than accept the servitude of his country, the phrase Acheronta uidebo represents a clear, though perhaps unexpected, echo of Vergil's Juno as she seeks to use the resources of hell, embodied in the Fury Allecto, to disrupt the Trojans' destiny: flectere si nequeo superos, Acheronta mouebo ("if I am unable to bend the gods, I will move hell," Aen. 7.312). The identical forms of Acheronta, the same placement of each phrase at the end of the line, and the similar inflections of the two verbs together strongly suggest a direct allusion. ${ }^{41}$ Moreover, Vergil's opposition between the gods above (superos) and the metonymic river below finds an analogue of sorts in Gestar's use of the phrase pro superi (368) in the very next line after Acheronta. The spatial contrast is less pointed than in Vergil, to be sure, but the diction nevertheless shows the same visual move, albeit in reverse, from the world below to the one above.

37 The effect of these changes from the source is crucial to the significance of the allusion: unlike Juno, Gestar is mortal and does not have recourse to the nether powers. His agency is defined not by moving hell but by going there, effectively via an act of suicide. In this Junonian context, Gestar's adverbial aeternum (367) recalls the programmatic use of the adjective - also aeternum - at Aen. 1.36, where it describes the goddess' "everlasting" resentment of the Trojans, which goes hand-in-hand with her favour towards Carthage and her consequent role in causing the Punic Wars. ${ }^{42}$ In both textual and historical senses, then, Gestar is a descendant of Vergil's Juno. 
At the same time, however, Silius makes us cognisant of the difference between Gestar's human and Juno's divine power - all the more so when later in the same book he will recapitulate Vergil's Juno-Allecto scene, swapping Allecto with Tisiphone. Indeed, Silius' Juno even utters the phrase Acheronta moues (Sil. 2.536), recalling both the Vergilian model and Gestar intratextually, as if to confirm the contrast between human and divine power implicit in the earlier shift from mouebo to uidebo - from a god marshalling hell to mortal suicide and now back to Juno's power. ${ }^{43}$ Gestar's Vergilian language thus does double duty in invoking politico-historical elements of the Aeneid as well as emphatically mythological elements (further substantiated by Silius' Juno), precisely the triangulation that plays out on a larger scale between Vergilian and Livian sources. In doing so, the allusions represent a key feature of Silius' macroscopic ambitions - the creation of an epic world that combines the full features of history and epic (in contrast to Lucan, for example) and casts the Punica as the historical and poetic sequel to the Aeneid. ${ }^{44}$

Silius' cultural construction of ethics at the outset of the debate - foedusque fidesque, etc. naturally agrees with the Roman envoy Fabius' own view of events at the end of the first debate (Sil. 2.380-1): at postquam discordia sensit / pectora et infidas ad Martem uergere mentes ("but when Fabius perceived their divided will and saw that their treacherous minds were inclining to war"). In another example of Hanno's Romanness, Fabius' infidas is preempted by Hanno himself when he focuses the charge of treaty-breaking and bad faith on Hannibal in particular (Sil. 2.297-8): conuersi foedere rupto / in caput infidum superi ("the gods who have turned against this treacherous man for breaking the treaty.") The discourse of fides continues in Hanno's second speech, against Mago in Book 11, where he claims that making peace with the Romans will remove Carthage's reputation for treachery (Sil. 11.5967): et fama fugetur ab urbe / perfidiae, Phoenissa, tua ("and the reputation for betrayal might be banished from your city, Dido"). In using language the same way Fabius and the narrator do, while the rest of the Senate is swept up in Hannibal's madness and initial accomplishments, Hanno appears to be the one Carthaginian who sees and judges correctly. In this, Silius' Hanno - just like Livy's Hanno - fits the mould of the "tragic warner," as several scholars have labelled the figure, the individual who warns a group that what they're doing or about to do is wrong and that they will suffer for it, but whose warning isn't believed. ${ }^{45}$ The possibility of Carthage's redemption - a striking counterfactual that turns the meaning of Punica fides on its head and thus creates a wholly new national identity - is embodied in Hanno, and yet he represents an almost comically unsuitable medium for an ostensibly positive message. ${ }^{46}$

"Ostensibly," because - as we argued in the case of Drances - the message is rather more freighted than critics have noticed, and it isn't easily separable from the person who bears it. In the last quotation, for instance, Hanno invokes Dido, founder of Carthage, as Phoenissa partly to allude to the stereotype of Punica fides, which he wishes to banish once and for all. But for anyone familiar with the Aeneid Hanno inevitably evokes Vergil's treatment of Dido, herself called Phoenissa (e.g., Aen. 1.714, 4.529), with fascinating consequences for the significance of good faith and bad. For in Book 4 of the Aeneid Dido three times calls Aeneas a traitor, perfidus (Aen. 4.305, 366, 421), for abandoning their love affair, which she sees as a de facto marriage, in favour of departing for Italy. Now, leaving aside the insoluble question of whether Dido's view is persuasive or not, what is much easier to appreciate is that in light of Vergil's Dido, Hanno's words possess a potent doubleness: he addresses Dido, Phoenissa, to wish for the end of Carthage's reputation for treachery, when, on another view, it was Aeneas' treachery and Dido's resulting curse that would cause the enmity between Carthage and Rome and lead directly to Hannibal's vengeance against Italy (Aen. 4.624-6, esp. nec foedera sunto at 624). ${ }^{47}$ 
41 These allusions to Dido are of a piece with Silius' other innovations in the treatment of Hanno: Silius repeatedly exploits Vergilian intertextuality to call into question his motives and character, and to cast doubt on his moral evaluations. Hanno's warnings may be as accurate as ever, but the bare fact of foreseeing the outcome of the war is arguably the least interesting feature of Silius' Hanno, since in that respect he merely follows his portrayal in the preceding tradition. If we are to register the full significance of Silius' characterisation, we must give due weight to the novel questions posed by the poet's highly suggestive juxtapositions, and these appear designed to turn the tragic warner into a figure more notable for moral dubiousness than oracular knowledge. If Silius' audience expected a versified rendition of Livy, replete with rhetorical flourishes suitable for controuersiae, they received more than they bargained for - whether they recognised it or not.

Thus far, it may seem as if Silius is largely playing Vergil against Livy in order to nuance the Carthaginian debate scenes and emphasise their multiple referentiality to Roman culture - in essence, a historiographical narrative of imperial heroism versus an epic narrative of civil (and divine) strife. Such a conclusion would do Livy, and Silius too, a great disservice. Indeed, the very generic distinction between prose and verse intertexts is far less clear than the two characterisations of Hanno - as an optimate and patriot in Livy, and as an invidious Romanophile in Silius - might initially suggest. ${ }^{48}$ For one thing, Hanno's hypocritical attitude to boys raised in military camps emerges from Silius' clever selection and arrangement of both Livian and Vergilian source material. But we needn't stop there: the Carthaginian debates contain a more spectacular example of such triangulation, which leads to some broader reflections on literary theory and Flavian epic intertextuality.

Livy had already broken down the prose-verse boundary through Hanno's selfcharacterisation as a uates (Livy 21.10.14), who not only predicts disaster for Carthage but also - for the reader - functions as a surrogate for the author as he projects the narrative of the Third Decade from its very beginning. Silius then picks up on and amplifies this metapoetic role through Hanno's self-reflexive words, haec serus uates Hannon canit (Sil. 2.285). But besides the Livian resonance, highlighted by Hanno's belatedness (serus), the verb canit also recalls Turnus' sarcastic condemnation of Drances' obsequious praise for the Trojans - capiti cane talia, demens, / Dardanio (Aen. 11.399-400) - an intertext based in part on the single verb cano but secured by the contextual resemblance between the two characters, Drances and Hanno, who praise the enemy to the heavens. The metapoetics of the word cano in the wake of the Aeneid's incipit hardly requires elaboration, and the mere threat of invoking mise-en-abyme may put off weary critics. ${ }^{49}$ But the vital consideration here is the particular role Hanno is playing, and the context in which he plays it - a speaker in a debate with other speakers, a politician engaged in diplomacy and international relations. ${ }^{50}$ Like Drances - and to a lesser extent like Gestar and Mago - Hanno is a mediator par excellence, a figure who functions as conduit, medium, and means of comparison. That role naturally befits the ambassador, councillor, or other representative, but it is also a role conferred by the context even on as predominantly epic a figure as Turnus - when that context is characterised by debate, negotiation, and diplomacy. Just as an ambassador, for example, acts as a representative for an individual, institution, or country, and at times departs from or resists that representative role, so too a figure such as Hanno sings like Livy, like Drances, like Vergil, like Silius himself, but not exactly like any one of them. And it is Silius too who functions as an intermediary negotiating so frequently between two authors, Vergil and Livy, and two genres of which those authors are themselves representatives, epic poetry and prose history. ${ }^{51}$

Authors and readers are always in the business of creating proxies - mental images of each other, their predecessors, their successors - but these proxies, like representatives and advisers, take on a life of their own, never fully under our control, since we know that our 
images of authors and audiences are always liable to shift in response to some new piece of information, insight, or perspective. Works of art are - at the level of production - the result of the negotiation between the competing demands of various groups, especially other writers and audiences, and - at the level of fiction - works of art are the stage on which proxies play out their ceremonial, representative, and communicative roles. As Silius' Carthaginian debates illustrate, debate and diplomacy are by definition conducted not through a single authoritative figure or speech - a prophet, an artist, a god, or a singer, to take the usual metapoetic paradigms - but rather through a space between speakers and their audience, where the characters play both parts - that of speaker and audience. Thus, we see modelled in these scenes a similar kind of negotiation to that between author and reader, one author and another, one text and another, one event and another. What lies at stake in the Carthaginian debates, then, is more than the fate of two empires: through their exchange, Hanno and his opponents negotiate the nature of the epic as well as the plot of history. And what emerges from this negotiation - this triangulation of source, proxy, and audience - is a poetic form enriched by the diverse content and idiom of Livy and Vergil, and uniquely suited to give an account of Roman identity past and present.

\section{Conclusion}

There is little question that computation speeds the process of identifying intertexts and that, as we argued in the introduction, it will be key to the feasibility of making non-binary intertextual comparisons (and of mapping intertextuality in non-canonical texts with the granularity already achieved for classical epic). It would be a mistake, however, to conclude that the value of computation starts and ends with the accumulation of increasingly long lists of parallels, just allowing the critic to the turn the crank on existing machinery faster and with less fatigue. Rather, an added value of this kind of quantitative scaling up - "big data," if you will - lies in its qualitative implications for literary criticism. We believe that our analysis of the Carthaginian debates, supported by a nascent interdisciplinary collaboration with computer scientists and bioinformaticians, reveals a few small hints of that promise.

The three computational tools used here - Diogenes, Tesserae, and sequence alignment - are united by many similarities. They are differentiated, however, in one specific way flexibility. The tools can be placed non-hierarchically on an axis of specificity, with Diogenes the most constrained in what it can find, sequence alignment the most expansive, and Tesserae somewhere in the middle. Constrained should not be taken as a negative descriptor here - Diogenes, as most classicists hardly need reminding, is an exquisite tool for finding repeated words, with almost no off-target results. The practical costs of sequence alignment's flexibility are a much lower signal to noise ratio and the need to tune multiple parameters to obtain useful results. The value of combinatorial application of tools, it should be clear, is greater than ever.

47 In its sensitivity to inexact similarity and broad applicability, sequence alignment is an excellent aid to the study of triangulation. Noting the complementarity, one might say that we simply chose the right tool for the job. Such a straightforward assessment, however, elides both the nascent status of computation in literary criticism and the productive symbiosis between methodology development and interpretative work that underlies our reading of Silian intertextuality. In some sense, it is difficult to assert any causal relationship between sequence alignment and triangulation. It is not that the enhanced capabilities of sequence alignment magically made possible a triangular study, any more than sequence alignment, which is supported by an enormous theoretical and empirical literature in computational biology, was purpose-designed for this particular application (or even for the study of intertextuality in toto). Perhaps a better statement is that a move toward more flexible forms 
of computation, which thrust inexact, non-blockbuster parallels out of the shadows, mirrors bidirectionally a hermeneutic move toward macro appreciation of non-binary intertextual networks. $^{52}$

Triangulation has proven an apt term not only for the " $n+1$ " process of computational search but also for the resulting literary critical negotiation of multiple source models. In both cases, the sense of triangulation used in the course of this essay has often been intuitive - a turning of a relationship between two texts into a relationship among three, or some extension thereof. In closing, however, we might add to the term a further significance drawn from the field of philosophy of language. Triangulation is also the name given to a theory, proposed by Donald Davidson, which was designed in part to address a number of philosophical questions about how we learn and use language, concerning in particular the objectivity of our interpretations of others' speech. ${ }^{53}$ Our interest here doesn't lie in debating the merits of Davidson's theory per se, which is as controversial as it is influential. ${ }^{54}$ Where the theory does intersect with our interests is in its implications for understanding the effects of intertextuality, especially in scenes of debate and diplomacy.

For our purposes, the salient component of Davidson's theory is the principle of charitable interpretation. According to this principle, one must charitably assume that other speakers share the same world as we do, and hence the objects, events, or concepts referred to in their speech are the same objects, etc. that we perceive in our experiential world. Triangulation thus consists in the act of a subject cross-referencing the speech of an interlocutor with the shared world to which both speakers are properly assumed to be referring, and it is through this process alone that communication can be successful. By extension, literary scholars have seen in this model a potential means of determining the validity of textual interpretation: they advert to the necessity for a shared world between author and audience to which the text is understood to refer. ${ }^{55}$ In both philosophical and literary contexts, then, the concept of a shared world is crucial as a basis of communication.

50 Intertextuality, however, complicates this process of making and understanding meaning. Consider, for instance, the effects of Silius' Hanno resembling Vergil's Drances as well as Livy's Hanno, contaminating one characterisation with another, and causing the reader to be unsure - if only for a moment - of the nature of the shared world to which Hanno, or Silius, is referring: is it Carthage or Rome? Is fides to be understood positively or ironically? Is the text in question a history or an epic? Intertextuality causes different meanings to arise by referring to one shared world rather than another, while at the same time allowing multiple worlds to co-exist, however uneasily. Davidson's theory, though contested and ultimately designed with other purposes in mind, nevertheless provides an attractive model against which the effects of intertextuality stand out more clearly. In identifying and parsing literary intertexts, we become more sensitive to the successes and failures of sharing worlds - between characters, between works, between critics - and to the questions of who is sharing what with whom. Viewed from that perspective, scenes of debate and diplomacy, wherein terms are already disputed and rival visions of the world are proferred - those scenes are especially liable to yield insights about communication of the most complex and self-reflexive kind.

51 It's against this context of shared meaning that we are perhaps best able to appreciate the role played by figures like Hanno (and Drances), which takes the communicative and representative function of the ambassador or councillor to the furthest extreme. For the majority of this essay, our purpose has been to highlight the effect of Silius' intertextuality to undermine Hanno, principally because critics have not fully registered the allusions and the interpretive significance of Silius' innovations against the Livian and Vergilian background. We added to this characterisation a sense of the mediating role played by Hanno, whose predictive powers in both Livy and Silius render him a figure (though not a precise figure) for the author. In the Punica, moreover, Hanno's conjoining of epic poetry and prose history - 
though perhaps already subtly present in Livy - represents a form of intergeneric mediation: oscillating between the strategic councillor of history and a Quisling-like figure of myth, Hanno gestures towards multiple realms of time, place, nationality, and explanatory discourse.

52 Such exuberant referentiality, especially in terms of identity and generic idiom, is a familiar feature of epic poetics: consider the mythico-historical Book 8 of the Aeneid, or Vergil's use of Epicurean philosophical language. But we wish to conclude with a slightly different observation. The very features that undermine Hanno as a character within the narrative - his almost eroticised affiliation with the Romans, his evocation of Drances - begin to take on a different significance in terms of his figural, mediating role. Hanno represents an overidentification with the other that sets him apart from the majority, and which defies the expectations underlying normal, everyday interpretation. The audience may anticipate a shared world of one kind, in which Carthaginians or genres conform to type, but a figure such as Hanno disrupts that notion with unusual explicitness and creates a world that is shared in a surprising and unfamiliar way. He is a Carthaginian separated from his brethren and bonded not only with second century Romans but also with a semihistorical Latin. In this way, the emotive demeanour of Hanno, which aligns him not with the people one would expect but with the supposed enemy, does not make him the "one good Carthaginian" - in fact, as we've seen, Silius goes to some lengths to reject that simplistic view. Rather, Hanno embodies the very principle of intertextual interpretation: a challenge to the idea of a single text inviting the reader into a single shared world. Instead one text aligns with another, almost decoupling from itself in the process, and one by one differently shared worlds proliferate for us to enter as our capacity and desire for identification permit.

\section{Bibliographie}

Ahl, F. 1985. Metaformations: Soundplay and Wordplay in Ovid and Other Classical Poets. Ithaca.

Altschul, S. F., W. Gish, W. Miller, E. Myers, and D. Lipman. 1990. "Basic local alignment search tool." J. Mol. Bio. 215: 403-10.

Ariemma, E. 2006. "Tentazioni demagogiche nei Punica di Silio Italico.” Aevum Antiquum 6: $217-42$.

Augoustakis, A. (ed.). 2014. Flavian Poetry and its Greek Past. Leiden.

Bernstein, N., K. Gervais, and W. Lin. Forthcoming. "Comparative rates of text reuse in classical Latin hexameter poetry.” Digital Humanities Quarterly 9.3.

Chaplin, J. 2000. Livy's Exemplary History. Oxford.

Chaudhuri, P. 2014. The War With God: Theomachy in Roman Imperial Poetry. Oxford.

Chaudhuri, P. 2015. "The Thebaid in Italian Renaissance Epic: The Case of Capaneus." Brill's Companion to Statius. Ed. W. Dominik, C. Newlands, and K. Gervais. Leiden: 52742. 
Chaudhuri, P. Forthcoming. "Embassies and Self-Representation in Silius' Punica." A Companion to Latin Epic, 14-96 CE. Ed. L. Fratantuono and C. Stark. Malden.

Coffee, N., J.-P. Koenig, S. Poornima, R. Ossewaarde, C. Forstall, and S. Jacobson. 2012. "Intertextuality in the Digital Age." TAPA 142: 383-422.

Coffee, N., J.-P. Koenig, S. Poornima, R. Ossewaarde, C. Forstall, and S. Jacobson. 2013. "The Tesserae Project: Intertextual analysis of Latin poetry." Lit. Ling. Comput. 28: 221-8.

Conington, J., and H. Nettleship. 1871. P. Vergili Maronis Opera: The Works of Virgil. Vol. 3. London.

Conte, G. B. 1986. The Rhetoric of Imitation: Genre and Poetic Memory in Virgil and Other Latin Poetry. Trans. C. Segal. Ithaca.

Cordell, R. 2013. “"Taken Possession of”: The Reprinting and Reauthorship of Hawthorne's 'Celestial Railroad' in the Antebellum Religious Press.” Digital Humanities Quarterly 7.1.

Cowan, R. 2009. "Virtual Epic: Counterfactuals, Sideshadowing and the Poetics of Contingency in the Punica." Brill's Companion to Silius Italicus. Ed. A. Augoustakis. Leiden: 323-51.

Dasenbrock, R. W. (ed.). 1993. Literary Theory After Davidson. University Park.

Davidson, D. 2001. Subjective, Intersubjective, Objective. Oxford.

Edmunds, L. 2001. Intertextuality and the Reading of Roman Poetry. Baltimore.

Feeney, D. C. 1982. A Commentary on Silius Italicus Book 1. Diss. Oxford University.

Feeney, D. C. 1984. “The Reconciliations of Juno.” CQ 34.1: 179-94.

Finn, E. 2012. "Becoming Yourself: David Foster Wallace and the Afterlife of Reception." The Legacy of David Foster Wallace. Ed. S. Cohen and L. Konstantinou. Iowa City: 151-76.

Fowler, D. 1990. “Deviant Focalisation in Virgil’s Aeneid.” PCPS 36: 42-63.

Ganascia, J.-G., P. Glaudes, and A. Del Lungo. 2014. "Automatic detection of reuses and citations in literary texts." Lit. Ling. Comput. 29: 412-21.

Ghiban, I. C., and S. Trăuşan-Matu. 2013. "Network Based Analysis of Intertextual Relations." Advances in Intelligent Systems and Computing 206: 753-62.

Hampton, T. 2009. Fictions of Embassy: Literature and Diplomacy in Early Modern Europe. Ithaca.

Hardie, P. 1990. "Flavian Epicists on Vergil's Epic technique.” The Imperial Muse: Flavian Epicist to Claudian. Ed. A. J. Boyle. Victoria: 3-20. 
Hardie, P. 1993. The Epic Successors of Virgil: A Study in the Dynamics of a Tradition. Cambridge.

Hardie, P. 1998. "Fame and Defamation in the Aeneid: The Council of Latins (Aeneid 11.225-467)." Vergil's Aeneid: Augustan Epic and Political Context. Ed. H.-P. Stahl. London: 243-70.

Henry, J. 1889. Aeneidea, or Critical, Exegetical, and Aesthetical Remarks on the Aeneis. Vol. 4. Dublin.

Hinds, S. E. 1998. Allusion and Intertext: Dynamics of Appropriation in Roman Poetry. Cambridge.

Horsfall, N. M. 2002. “Sallustian politicians and Virgilian villains.” SCI 21: 79-81.

Isaac, B. H. 2004. The Invention of Racism in Classical Antiquity. Princeton.

Knauer, G. N. 1964. Die Aeneis und Homer: Studien zur poetischen Technik Vergils mit Listen der Homerzitate in der Aeneis. Göttingen.

Landrey, L. 2014. "Skeletons in Armor: Silius Italicus' Punica and the Aeneid's Proem." AJP 135.4: 599-635.

Lavan, M. 2013. Slaves to Rome: Paradigms of Empire in Roman Culture. Cambridge.

Maltby, R. 1991. A Lexicon of Ancient Latin Etymologies. Leeds.

Manuwald, G., and A. Voigt (ed.). 2013. Flavian Epic Interactions. Berlin.

Momigliano, A. 1990. Alien Wisdom: The Limits of Hellenization. Cambridge.

Nicol, J. 1936. The Historical and Geographical Sources Used by Silius Italicus. Oxford.

Olsen, M., R. Horton, and G. Roe. 2010. "Something Borrowed: Sequence Alignment and the Identification of Similar Passages in Large Text Collections." Digital Studies / Le Champ Numérique 2.1.

Pomeroy, A. J. 2009. "To Silius through Livy and his Predecessors." Brill's Companion to Silius Italicus. Ed. A. Augoustakis. Leiden: 27-46.

Pomeroy, A. J. 2010. "Fides in Silius Italicus' Punica." Silius Italicus: Akten der Innsbrucker Tagung vom 19.-21. Juni 2008. Ed. F. Schaffenrath. Frankfurt: 59-76.

Roskies, A. L. 2011. "Triangulation and objectivity: Squaring the circle?" Triangulation: From an Epistemological Point of View. Ed. C. M. Amoretti and G. Preyer. Frankfurt: 97102.

Smolenaars, J. J. L. 1994. Statius Thebaid 7: A Commentary. Leiden.

Spaltenstein, F. 1986. Commentaire des Punica de Silius Italicus (livres 1 à 8). Geneva. 
Spaltenstein, F. 1990. Commentaire des Punica de Silius Italicus (livres 9 à 17). Geneva.

Stocks, C. 2014. The Roman Hannibal: Remembering the Enemy in Silius Italicus' Punica. Liverpool.

Thomas, R. F. 1986. "Virgil's Georgics and the Art of Reference." HSCP 90: 171-98.

Verheggen, C. 2007. “Triangulating with Davidson.” Philosophical Quarterly 57: 96-103.

Woodman, A. J., with C. S. Kraus 2014. Tacitus: Agricola. Cambridge.

\section{Notes}

1 See Edmunds 2001.

2 Formative applications include Conte 1986, Hinds 1998. A paradigmatic example of older studies of allusion is Knauer 1964.

3 E.g., Augoustakis 2014, Manuwald and Voigt 2013. PC discusses Flavian intertextuality with Greek and Roman predecessors in Chaudhuri 2014, and with Italian Renaissance successors in Chaudhuri 2015.

4 The core intertextuality search tool developed by the Tesserae Project is available at the following URL: http://tesserae.caset.buffalo.edu/. See Coffee et al. 2012 and 2013 for an overview of the project.

5 On Drances and Livy's Hanno see Conington and Nettleship 1871: 336; on Drances and Silius' Hanno see Henry 1889: 181.

6 Hardie 1990. A notable study of combinatorial allusion in Flavian epic is J. J. L. Smolenaars' commentary on Thebaid 7 (Smolenaars 1994). For earlier discussions of allusions to multiple authors see Conte 1986 and Thomas 1986.

7 The term is borrowed, not coincidentally, from Donald Davidson's theories of interpersonal communication. Although beyond the scope of the present article, a fuller application of Davidsonian triangulation to literary intertextuality may prove extremely fruitful. See the conclusion for preliminary remarks in that direction.

8 Indeed the "source" tag too can be jettisoned. An appealing feature of a triangular model is that by default it implies neither hierarchy nor chronology, facilitating the practice, now standard in classical reception studies, of reading backwards from a later to earlier text. One might also exploit the structure to infer information about one of the three vertices solely from the other two, in closer analogy to triangulation in geometry and orienteering.

9 Although still largely unexplored in classics, network analyses, whether involving characters in a single work, a set of mutually allusive texts, or moments of artistic or critical reception, have had ample influence in literary criticism. For specific examples see Cordell 2013, Finn 2012, and Ghiban and Trăuşan-Matu 2013. The Stanford Literary Lab (https://litlab.stanford.edu/), co-directed by Franco Moretti and Mark Algee-Hewitt, has pioneered the application of network analysis to modern literature.

10 Spaltenstein 1986 and 1990.

11 Many similarity scores besides edit distance exist, but they all follow the same basic principle.

12 Altschul et al. 1990. A widely-used implementation of BLAST is available through the National Center for Biotechnology Information at the following URL: http://blast.ncbi.nlm.nih.gov/Blast.cgi.

13 Hinds 1998: 50.

14 This character-by-character approach distinguishes our methodology from other applications of sequence alignment in literary study, which take complete pairs of words (or longer strings) as their 
basic unit. Examples of such methods, though not applied with classical languages in mind, include PhiloLine and Text::Pair (http://code.google.com/p/text-pair/). See Olsen et al. 2010, and J.-G. Ganascia et al. 2014.

15 The technical details of the tool will be described in a forthcoming publication, which will also report the results of ongoing testing using objective protocols.

16 The Diogenes software is available for download (along with substantial documentation) at the following URL: https://community.dur.ac.uk/p.j.heslin/Software/Diogenes/.

17 See the references in $\mathrm{n} .4$ for additional information on the Tesserae methodology.

18 Coffee et al. 2012.

19 Bernstein et al. forthcoming.

20 Candidates include experimental topic modeling and semantic matching tools now under development by the Tesserae Project (http://tesserae.caset.buffalo.edu/cgi-bin/lsa.pl).

21 We say "apparent" because it is unclear why the parallel between Vergil's equidem ... minetur and Silius' quidem ... minantum did not appear in the Tesserae results.

22 Similar morphological endings can be thought of as part of a general class of phonetic resemblances, whether in ending, root, or even at the level of individual syllables. Character-bycharacter sequence alignment is inherently well attuned to detect similarities in sound based on phonetic units constituted by letters. A further advantage of sequence alignment is that it can aid in the detection of anagrams, as illustrated here by the relationship between toruum and mortuum discussed above. As such we have also developed a tool for detecting anagrams that uses a similar method. The details of this tool will be reported in a publication now in preparation. On the role of the syllable in Latin soundplay see Ahl 1985.

23 The quotation is from Coffee et al. 2012: 396. See Conte 1986: 31 for further discussion of code models. Tesserae is especially effective at detecting reuse of formulaic phrases since the underlying method is based on two-word pairs and can account for morphological variations. In this context note Tesserae's identification of patribusque uocatis as a formula linking Sil. 2.383 and Aen. 11.379 .

24 These results were obtained - indeed, could only be obtained - when the cutoff score set by the tester was equal to the edit distance or greater.

25 The search query consisted of these four words, exclusive of any intervening words. As mentioned above, our input terms consisted of phrases of central importance to the line or passage at hand, including verb-direct object pairs (as seen here).

26 Spaltenstein 1986: 140.

27 The only other instance of incendia belli occurs at Argonautica 6.739 (again occupying the second half of the line), when Perses rushes headlong into the "heat of battle" against the Colchians. The phrase incendium belli appears only at De Republica 1.1.3, notably in a passing reference to the nascent Second Punic War. Silius might have had Cicero's text in mind as well.

28 This parallel was discovered through the use of both the sequence alignment tool and Diogenes. A search for conuersi foedere rupto using the former yielded poenam foederis rupti (Livy 21.6.6) at a cutoff of 10. A Diogenes search for "bell absist" (in place of the phrase bello absistis) pointed to absisteretur bello (21.6.6). Silius in effect collapses two embassies reported by Livy into one, such that the language drawn from Valerius and Baebius' mission appears in the context of the later mission led by Fabius. On the relation between Silius and his historical sources see Pomeroy 2009, Nicol 1936; an up-to-date book-length treatment is a desideratum.

29 On this passage see Chaudhuri 2014: 238.

30 See n. 5 above.

31 Spaltenstein 1986: 133.

32 The relatively extensive discussion of the intertextuality between Silius' Hanno and Vergil's Drances in Ariemma 2006 mentions Livy only in passing.

33 On strategies for dealing with such hermeneutic multiplicity (exemplified by the problem of focalisation but broadly applicable to intertextuality too) see Fowler 1990.

34 See Maltby 1991: s.v. foedus. The word fides plays a crucial role in the Roman representation of the Second Punic War and indeed of the Carthaginians in general, notoriously in the oxymoronic and sarcastic phrase Punica fides, and Silius is no exception in his frequent reference to the concept. 
On Roman (and Greek) stereotypes of the Carthaginians see Isaac 2004: 324-35. On fides in the Punica see Pomeroy 2010, and the forthcoming proceedings of the conference on fides in Flavian literature held at Radboud University Nijmegen.

35 Silius' treatment of the concept of foedusque fidesque in the Punica is far more nuanced than hinted at by this stark opposition in Book 2. When, in the katabasis of Book 13, Scipio confronts the shade of Hamilcar about Hannibal's treaty-breaking (taliane, o fraudum genitor, sunt foedera uobis?, Sil. 13.738), Hamilcar responds by citing his son's devotion (o pietas, o sancta fides, Sil. 13.749) not only to his father but also to the gods by whom the young Hannibal had sworn his oath of vengeance. The Roman pedigree of such virtues is indisputable, even if critics have debated whether Hannibal ultimately perverts them, or whether the values themselves serve purely personal ends to the detriment of the state. In any case, Silius allows Hamilcar the last word in this exchange, leaving the reader with a very different impression of foedusque fidesque - as an idea far more open to contestation - than the one implied in the passage in Book 2. On Hannibal's Roman qualities see Stocks 2014.

36 Hardie 1998: 261.

37 See Hardie 1998: 245, with further references, and Horsfall 2002. Silius repeatedly gestures towards the problems the Roman republic will face after the fall of Carthage, which are supposedly caused by the removal of the metus hostilis (e.g., Sil. 3.588-90), so he is keenly aware of the very discord that Drances prefigures.

38 Cf., e.g., Met. 9.398 (Iolaus), Theb. 9.703 (Parthenopaeus). Spaltenstein ad loc. notes this and other similar intertexts, but not the crucial implications of the Vergilian passage, nor the highly germane moralising of Livy's Hanno.

39 Cf, e.g., Sil. 2.362 and Aen. 11.438 (the intertext was noted in the same Tesserae search as n. 40 below; it was scored at 10). On Gestar as Turnus see Ariemma 2006: 221-2.

40 A Tesserae comparison of Punica 2 against the whole of the Aeneid revealed two intertexts for the phrase pro libertate, both scored at 10, that strengthen the Roman quality of Gestar and which are not found in Spaltenstein: Aen. 6.821 (used of Brutus, who values republican freedom above the lives of his own sons), and 8.648 (used of the Romans who willingly sacrifice their lives in resisting Porsenna). The same search revealed another intertext, also scored at 10, between Gestar and Mezentius, opponent of Aeneas. The Etruscan envisages his horse, Rhaebus, dying with him and avoiding the prospect of bearing a Trojan master (occumbes at Aen. 10.865 echoed in Silius' occumbam at 366). Silius thus combines in one Carthaginian nationalist a desire for autonomy seen in both Vergil's Romans and the enemies of Aeneas. Gestar's commitment to libertas should also be compared with the rhetoric of Calgacus in Tacitus' Agricola, on whom see Woodman 2014: 19-25, and Lavan 2013: 127-42.

41 This is a good example of the kind of intertext amenable to discovery by sequence alignment but not, for instance, the Tesserae methodology. Since Tesserae focuses on the presence of the same pair of words across two texts, and since there is no such pair between the Silian and Vergilian lines, no parallel is logged. A sequence alignment search, by contrast, reveals the Vergilian intertext (at a cutoff of 6) because of the character-by-character similarity between the two phrases, even though the verbs are unrelated in meaning. Diogenes would include the Vergilian passage if searching for Acheronta alone, but not if searching for Acheronta uidebo.

42 On the temporal extent of Juno's anger in the Aeneid see Feeney 1984.

43 The attribution of agency to the Fury implied by the 2nd person verb moues (whereas Vergil's 1st person mouebo locates the agency in Juno herself) is consistent with the increased powers of hell in Silver Latin epic. See Hardie 1993.

44 On Flavian epic's response to Lucan's theology see Chapters 6-8 of Chaudhuri 2014.

45 Chaplin 2000: 78-9.

46 On counterfactuals in the Punica see Cowan 2009.

47 Cf. Momigliano 1990: 5: "Vergil came near to transferring Punica fides to Aeneas."

48 Silius does not alter Hanno's status as a member of the senatorial elite, but the allusions to Drances - a demagogue of mixed background (his mother is noble, but his father's origins are unknown; cf. Aen. 11.340-1) - necessarily colour our perception of Hanno and emphasise class issues that are more subtly present in Livy (21.4.1). 
49 On Silius' repeated allusions to the incipit of the Aeneid, specifically the arma uirumque collocation, see Landrey 2014.

50 For a similar treatment of "diplomatic poetics" in early modern culture see Hampton 2009. For an initial application of some of Hampton's ideas to classical literature see Chaudhuri forthcoming.

51 Silius signals his dual literary and historical parentage from the outset of the Punica: the incipit ordior arma alludes to both Livy and Vergil. Besides the resonance of arma with the opening of the Aeneid, participial forms of ordior appear twice in the last sentence of Livy's preface. See Feeney 1982 ad loc.

52 Computation, of course, forces the critic to confront " $n$-angulation" in other ways. To give only one example, consider the Tesserae user interface, which contains drop-down menus with almost all extant classical material. Given such a resource, it would take a real failure of imagination (if not overt laziness) for a critic not to make a few additional comparisons and see what turns up.

53 The theory is adumbrated across many of Davidson's publications, but the key discussions can be found in the essays in Davidson 2001. Triangulation has several varied and crucially important functions in Davidson's philosophy, which ramify well beyond the narrow concern with language relevant here.

54 One useful entree into the philosophical discussion, though avowedly in Davidson's camp, is Verheggen 2007; see also Roskies 2011.

55 On triangulation's role in literary theory see Dasenbrock 1993. 